\title{
Technical and Financial Aspects of White Shrimp (Litopenaeus vannamei) Culture in Coastal Sandy Soil Area of Bantul Regency
}

\author{
Bambang Triyatmo, Suadi, Dian Ambarwati, and Sukardi \\ Department of Fisheries, Gadjah Mada University, Yogyakarta \\ Email: btriyatmo@yahoo.com
}

\begin{abstract}
Bambang Triyatmo, Suadi, Dian Ambarwati, and Sukardi. 2016. Technical and Financial Aspects of White Shrimp (Litopenaeus vannamei) Culture in Coastal Sandy Soil Area of Bantul Regency. Aquacultura Indonesiana, 17 (2): 54-59. This research was conducted to know the technical and financial aspects of white shrimp (Litopenaeus vannamei) culture in coastal sandy soil area of Bantul Regency. The samples of farmers were determined by stratified sampling method based on the ponds width. The data were colected by observation and interviews methods. The samples in the study were 41 farmers as respondents perponds from the population of 290 ponds. Samples were consisted of three categories : $1,000 \mathrm{~m}^{2} /$ pond for 16 farmers: $1,000-1,500 \mathrm{~m}^{2} /$ ponds for 14 farmers and $>1,500-2,500 \mathrm{~m}^{2} /$ pond for 11 farmers. The results showed that the white shrimp culture in Bantul District coastal sandy soil area was an intensive system with average pond width $1,300 \mathrm{~m}^{2}$. Average pond category $<1,000 \mathrm{~m}^{2}$ was $636 \mathrm{~m}^{2}$; average pond category $1,000-1,500 \mathrm{~m}^{2}$ was $1,357 \mathrm{~m}^{2}$ and average pond category $>1,500-2,500 \mathrm{~m}^{2}$ was $2.191 \mathrm{~m}^{2}$. Generally the fixed costs incurred IDR 24,876,128/pond/cycle and variable costs IDR 72,839,121/pond/cycle (IDR 218,517,362/pond/year). The revenue of the culture was IDR 109,709,805/pond/year, with the ratio value between the total revenue with total costs [Revenue (R)/Cost (C) ratio] was 1.37. The Break Event Point (BEP) of shrimp products was 4,909 $\mathrm{kg}$ and the Break Event Point (BEP) of shrimp price was IDR 34,312. The highest productivity of shrimp was 19.7 ton/ha/cycle, which be cultured in the 1,000-1,500 $\mathrm{m}^{2}$ ponds, with incomed IDR 169,507,143/pond/cycle and the Revenue/Cost ratio (R/C ratio) was 1.60. The BEP of shrimp products was 5,069 $\mathrm{kg}$ and the BEP of shrimp price was IDR 28,187.
\end{abstract}

Keywords : Bantul Regency; Coastal; Financial; Shrimp and technical

\section{Introduction}

Shrimp farming has been one of the fastest growing aquaculture sectors in Asia. Rapid expansion of shrimp farming has generated substantial income for many developing countries, as well as developed countries, including Indonesia (FAO/NACA/UNEP/WB/WWF, 2006). Most of coastal area in Indonesia, especially in the north coast of Java island are overexploited. Alternative way to increase shrimp production was in many parts of the south coast of Java island. The white shrimp farming in the south coast is rapidly growth (Djumanto et al., 2016). Study in the south coastal area of Ngombol Districts Purworejo Regency indicated that the sandy area was unsuitable for pond construction, unfertile and slightly to neutral soil (Triyatmo, 2001). The coastal sand dunes and beach ridge land areas of Purworejo Regency have slopes 2$8 \%$, sandy soil texture, and $\mathrm{pH}$ average 7.2 (ranges 6.6-7.4). The potential sustainable of the coastal area for shrimp-culture ponds were classified as rather suitable (S3). The main problems of unsuitable for shrimp-culture ponds were sandy textured soils. The potential of water sources for shrimp-culture ponds can be taken from seawater directly or from groundwater in coastal areas (Triyatmo, 2015).

The potential of white shrimp culture in coastal sandy soil area of Bantul Regency is great due to large land area for ponds, good supply water and adequate infrastucture. The land clearing of sandy soil area to shrimp farms by local residents led to increased productivity which initially unproductive land into productive land. Technical and financial analysis of shrimp culture in the coastal of Bantul Regency needs to be done to determine the income and expense information needed in the process of shrimp culture, and determine the success of farming. The white shrimp culture in the coastal sandy soil area of Bantul Regency has been growing rapidly since 2012. The rapid development of white shrimp culture during last five years was due to the technological development that come with plastic mulch to the sandy land and water uptake through absorption wells by pumped (Suparyanti et al., 2015; Ambarwati et al., 2016). Development of shrimp farming techniques uses plastic to cover the sandy soil. This is a new technology that used by the farmers. The use of 
this plastic aims to reduce the amount of water absorption that occurs in the sand. Feasibility enlargement the white shrimp (L. vannamei) can be known through the technical and financial analysis of cultivation activities.

\section{Materials and Methods}

The study was conducted between July and August 2015 in coastal area of Bantul Regency (geographical position : $110^{\circ} 12^{\prime} 36^{\prime \prime}-110^{\circ}$ 20 '25" E; $7^{\circ} 58^{\prime} 37$ " $\left.-8^{\circ} 02^{\prime} 19^{\prime \prime} \mathrm{S}\right)$. The location determination was purposive with consideration in coastal areas were found many shrimp farmers. A number of 41 shrimp ponds located in four villages within the districts i.e., Poncosari, Gadingsari, Srigading and Parangtritis were visited. The method used in shrimp farmer sampling was stratified random sampling. The research sample was descriptive of at least $10 \%$ of the population and at least $20 \%$ for a very small population (Gay and Diehl, 1992). This study sampled $14 \%$ of the population (290 ponds) that was about 41 respondents. The respondents were the shrimp pond owners/farmers. The size area of shrimp ponds could be categorized into three groups as shown in Table 1, that are : $<1,000 \mathrm{~m}^{2} /$ pond; 1,000 $1,500 \mathrm{~m}^{2} /$ pond and $>1,500-2,500 \mathrm{~m}^{2} /$ pond. Number of respondents as famers who managed the ponds were 16 farmers of $<1,000 \mathrm{~m}^{2} /$ pond category; 14 farmers of $1,000-1,500 \mathrm{~m}^{2} /$ pond category and for 11 farmers of $>1,500-2,500$ $\mathrm{m}^{2} /$ pond category. Primary data collected were fixed and variable costs using in depth interview of the shrimp pond owners (see Table 2 and Table 3). Fixed cost data includes manufacture, depreciation (shrinkage) tool, electricity, salary and others (see Table 2). Variable cost data includes seeds, feed, fuel oil, limes/fertilizers, probiotic/medicine, harvesting (see Table 3). Secondary data were obtained from the data recording of the agency or institutions related to the purpose of research. The institution may be a fish farmer groups, Shirmp Club Indonesia (SCI), Fisheries Department of Bantul Regency.

Revenue is the goal to be achieved by farmers who manage their farm. Farmers income is the difference between revenue and all expense costs. Farmers income is used for the analysis is the net revenue. Net farmers income (I) is useful to measure the profitability of farmers from year to year.

Net farmers income was calculated using the formula : $\mathrm{I}=\mathrm{TR}-\mathrm{TC}$.
The analysis of Revenue (R)/Cost (C) ratio is defined by limit the amount of the smallest ratio and still be considered beneficial or feasible is 1 . Value ratio (a) is greater than one $(>1)$, then the business is said to be profitable and feasible to continue (Yacob, 2003).

Mathematically can be written : $\mathrm{a}=\mathrm{R} / \mathrm{C}$

Where : $\mathrm{R}=\mathrm{Pq} \times \mathrm{Q} ; \mathrm{C}=\mathrm{FC}+\mathrm{VC}$ and $\mathrm{a}=[(\mathrm{PqxQ}) /$ $(\mathrm{FC}+\mathrm{VC})]$.

The Analysis of Break Event Point (BEP) shows that the level of production generated revenue equal to the production cost.

BEP was calculated using the formula :

$\mathrm{TR}=\mathrm{TC} ; \mathrm{Q} \cdot \mathrm{Pq}=\mathrm{FC}+\mathrm{VC} \cdot \mathrm{Q}$ and $\mathrm{BEP}(\mathrm{Q})=\mathrm{FC} /$ (Pq-VC).

BEP was also expressed in Rupiah (IDR) using the formula :

$\mathrm{BEP}=\frac{F C}{(1-V C / P q)}$

Where I : Income; TR : Total Revenue; TC : Total Cost $; \mathrm{FC}=$ Fixed costs; $\mathrm{VC}=$ Variable Costs; $\mathrm{Q}=$ Total Production and $\mathrm{Pq}=$ Price of Production )

\section{Results and Discussion}

The technical and financial analysis of the shrimp culture which work done on shrimp farmers in the coastal sandy soil area of Bantul Regency will describe the technique and the farmers income. The technical analysis was aimed to know the technical factors which affected the production of shrimp. Shrimp culture was aimed to increase revenue and prosperity of farmers. Financial analysis of shrimp culture was aimed to determine the investment required for the operation of a shrimp culture per cycle, so that the farmers could find profit and benefit.

The size area of shrimp pond would affected the fixed and variable cost, increasing of pond size would make the total cost increased. Based on census to the fields and interview to the farmers, the number of ponds in Bantul Regency coastal area were 290 ponds (company farms not yet included). The number of ponds based size into three groups as shown Table 1. Table 1 shows that most shrimp ponds of $<1.000 \mathrm{~m}^{2} /$ pond category, while the other ponds were bigger. The shrimp culture were harvested three times a year with harvest cycle of every four months.

The result showed that generally (see Table 1), the white shrimp culture in coastal sandy soil area of Bantul Regency was an 
intensive system; ponds sized ranged from 1.000 $\mathrm{m}^{2}$ to $2.500 \mathrm{~m}^{2}$ per pond with average pond width $1,300 \mathrm{~m}^{2}$; the stocking density $146 \mathrm{seed} / \mathrm{m}^{2}$; the feed (33-36\% protein) was given as much as $2,668 \mathrm{~kg} / \mathrm{pond} /$ cycle $(20.5 \mathrm{tons} / \mathrm{ha} /$ cycle); the 83 days of culture; shrimp production of 2,275 $\mathrm{kg} / \mathrm{pond} /$ cycle (17.5 ton/ha/cycle) and feed conversion ratio (FCR) 1.2. The white shrimp culture used paddle-wheel 20 fans of paddlewheels/pond (152 fans of paddle-wheels/ha); water exchange $10 \%$ days; calsite $6,534 \mathrm{~kg} / \mathrm{ha}$; dolomite 3,350 kg/ha; Effective for microorganisms (Em4) 292 L/ha; mollases 720 $\mathrm{kg} / \mathrm{ha}$; brans $1,019 \mathrm{~kg} / \mathrm{ha}$; B and C vitamins 11 L/ha.

Table 1. The technical and financial data of white shrimp (Litopenaeus vannamei) culture in coastal sandy soil area of Bantul Regency

\begin{tabular}{|c|c|c|c|c|c|}
\hline \multirow{2}{*}{ Parameter } & \multirow{2}{*}{ Unit } & \multicolumn{4}{|c|}{ Category of ponds width $\left(\mathrm{m}^{2}\right)$} \\
\hline & & $<1,000$ & 1,000 to 1,500 & $>1,500$ to 2,500 & $<1,000$ to 2,500 \\
\hline Population & Pond & 190 & 57 & 43 & 290 \\
\hline Repondens & Farmers/Pond & 16 & 14 & 11 & 41 \\
\hline Pond & $\mathrm{m}^{2}$ & 636 & 1.357 & 2.191 & 1.300 \\
\hline Density & Seeds $/ \mathrm{m}^{2}$ & 141 & 161 & 134 & 146 \\
\hline \multirow{2}{*}{ Feed } & $\mathrm{kg} /$ pond/cycle & 1,466 & 3,275 & 3,481 & 2,668 \\
\hline & ton/ha/cycle & 23.1 & 24.1 & 17.5 & 20.5 \\
\hline \multirow[t]{2}{*}{ Produktivity } & $\mathrm{kg} /$ pond/cycle & 1,106 & 2,673 & 3,220 & 2,275 \\
\hline & ton/ha/cycle & 17.4 & 19.7 & 14.7 & 17.5 \\
\hline Feed Convertion Ratio & Unit & 1.3 & 1.2 & 1.1 & 1.2 \\
\hline \multirow[t]{2}{*}{ Fix Cost } & IDR./pond/cycle & $15,338,411$ & $25,536,131$ & $37,909,167$ & $24,876,128$ \\
\hline & IDR./pond/year & $46,015,234$ & $76,608,393$ & $113,727,500$ & $74,628,384$ \\
\hline \multirow[t]{2}{*}{ Variable Cost } & IDR./pond/cycle & $35,744,547$ & $80,720,800$ & $116,763,636$ & $72,839,121$ \\
\hline & IDR./pond/year & $107,233,641$ & $242,162,400$ & $350,290,909$ & $218,517,362$ \\
\hline \multirow[t]{2}{*}{ Total cost } & IDR./pond/cycle & $51,082,958$ & $106,256,931$ & $154,672,803$ & $97,715,249$ \\
\hline & IDR./pond/year & $153,248,875$ & $318,770,793$ & $464,018,409$ & $293,145,746$ \\
\hline \multirow[t]{2}{*}{ Income } & IDR./pond/cycle & $64,231,875$ & $169,507,143$ & $190,570,455$ & $134,075,244$ \\
\hline & IDR./pond/year & $192,695,625$ & $508,521,429$ & $571,711,364$ & $402,225,732$ \\
\hline Revenue & IDR./pond/year & $39,446,750$ & $189,750,636$ & $107,692,955$ & $109,079,985$ \\
\hline R/C Ratio & Unit & 1.26 & 1.60 & 1.23 & 1.37 \\
\hline BEP product & $\mathrm{kg}$ & 2,722 & 5,069 & 7,884 & 4,909 \\
\hline BEP price & IDR. & 37,483 & 28,187 & 37,494 & 34,312 \\
\hline
\end{tabular}

Explain : R/C = Revenue/Cost; $\mathrm{BEP}=$ Break Event Point; 1 year $=3$ cycle

Table 2. Fix Cost (IDR/pond/year)

\begin{tabular}{lrrrrrrr}
\hline \multirow{2}{*}{ Parameter } & \multicolumn{2}{c}{$<1,000 \mathrm{~m}^{2}$} & \multicolumn{2}{c}{$1,000-1,500 \mathrm{~m}^{2}$} & \multicolumn{2}{c}{$>1,500-2,500 \mathrm{~m}^{2}$} & \multirow{2}{*}{ Average } \\
\cline { 2 - 7 } & Cost (IDR) & \multicolumn{1}{c}{$\%$} & Cost (IDR) & \multicolumn{1}{c}{ Cost (IDR) } & \multicolumn{1}{c}{$\%$} & \\
\hline Manufactor & $22,048,438$ & 47.92 & $47,842,857$ & 62.45 & $74,027,273$ & 65.09 & $44,801,829$ \\
Shrinkage tool & $5,946,172$ & 12.92 & $11,686,964$ & 15.26 & $21,627,500$ & 19.02 & $12,113,628$ \\
Electricity & $1,020,625$ & 2.22 & 78,571 & 0.10 & $1,072,727$ & 0.94 & 712,927 \\
Salary & $12,000,000$ & 26.08 & $12,000,000$ & 15.66 & $12,000,000$ & 10.55 & $12,000,000$ \\
Others & $5,000,000$ & 10.87 & $5,000,000$ & 6.53 & $5,000,000$ & 4.40 & $5,000,000$ \\
\hline Total & $46,015,234$ & 100.00 & $76,608,393$ & 100.00 & $113,727,500$ & 100.00 & $74,628,384$ \\
\hline
\end{tabular}

Table 3. Variable Cost (IDR/pond/cycle)

\begin{tabular}{lrrrrrrr}
\hline \multirow{2}{*}{ Parameter } & \multicolumn{2}{c}{$<1,000 \mathrm{~m}^{2}$} & \multicolumn{2}{c}{$1,000-1,500 \mathrm{~m}^{2}$} & \multicolumn{2}{c}{$>1,500-2,500 \mathrm{~m}^{2}$} & \multirow{2}{*}{ Average } \\
\cline { 2 - 7 } & Cost (IDR) & \multicolumn{1}{c}{$\%$} & \multicolumn{1}{c}{ Cost (IDR) } & \multicolumn{1}{c}{$\%$} & Cost (IDR) & \multicolumn{1}{c}{$\%$} & \\
\hline Seed & $3,776,375$ & 10.56 & $9,110,714$ & 11.29 & $12,011,818$ & 10.29 & $7,807,366$ \\
Feed & $20,131,250$ & 56.32 & $50,505,943$ & 62.57 & $59,904,545$ & 51.30 & $41,173,980$ \\
BBM & $9,940,500$ & 27.81 & $15,490,286$ & 19.19 & $39,600,000$ & 33.91 & $19,792,976$ \\
Liming & 313,375 & 0.88 & 416,000 & 0.52 & 614,545 & 0.53 & 429,220 \\
Probiotic & 477,797 & 1.34 & $1,494,286$ & 1.85 & $1,416,818$ & 1.21 & $1,076,823$ \\
Harvest & $1,105,250$ & 3.09 & $3,703,571$ & 4.59 & $3,215,909$ & 2.75 & $2,558,756$ \\
\hline Total & $35,744,547$ & 100.00 & $80,720,800$ & 100.00 & $116,763,636$ & 100.00 & $72,839,121$ \\
\hline
\end{tabular}


The other result showed that the white shrimp culture in Pandansimo Village coastal area of Bantul Regency was an intensive system with average pond width $1,206 \mathrm{~m}^{2}$, the stocking density $193 \mathrm{seed} / \mathrm{m}^{2}$, the feed $(33-36 \%)$ was given as much as $3,216 \mathrm{~kg}(26.4 \mathrm{ton} / \mathrm{ha})$, the 83 days of culture, shrimp production of $2,574 \mathrm{~kg}$ (21.3 ton/ha) and feed conversion ratio (FCR) 1.26. The technique of white shrimp culture used 23 fans of paddle-wheels/pond (190 fans of paddle-wheels/ha); water exchange $0-15 \% /$ days; calsite $5,402 \mathrm{~kg} / \mathrm{ha}$; dolomite $4,902 \mathrm{~kg} / \mathrm{ha}$; zeolite $133 \mathrm{~kg} / \mathrm{ha}$; probiotic and additive ingredients: Effective for organisms (Em4) 164 bottle/ha; Bioacces 198 bottle/ha; New lacto 0.33 bottle/ha; mollases $720 \mathrm{~kg} / \mathrm{ha}$; brans $3,287 \mathrm{~kg} / \mathrm{ha}$; Curcumas 7.17 bottle/ha; provet milks 5.39 $\mathrm{kg} / \mathrm{ha}$; duck eggs $1.16 \mathrm{~kg} / \mathrm{ha}$; B and $\mathrm{C}$ vitamins 1.80 bottle/ha. The white shrimp culture in Pandansimo coastal area was feasible (Suparyanti et al., 2015 ${ }^{\mathrm{a}}$ ).

The white shrimp culture in Bantul Regency coastal area showed that the 1,000$1,500 \mathrm{~m}^{2}$ category pond was the most good. White shrimp cultivation in the Bantul Regency coastal area had a ratio of revenue to cost $(\mathrm{R} / \mathrm{C})$ 1.60 (more than 1), so it can be said cultivation is feasible to proceed (see Table 5). Shrimp production $(1,106 \mathrm{~kg}-3,220 \mathrm{~kg})$ less than the break-even point products $(2,722-7,884 \mathrm{~kg})$, with it the conclusion that the fish farmers have to increase shrimp production to cover production costs. The selling price of shrimp (IDR 56,938 IDR 62,857) was greater than the break-even point of price (IDR 28,187 - IDR 37,494), so that white shrimp farming has cover all operation and maintenance costs as well as capital costs incurred.

The production of vannamei shrimp ponds in in coastal sandy soil area of Bantul Regency in catagories $<1.000 \mathrm{~m}^{2}$ was $1,105 \mathrm{~kg} /$ pond/cycle (17.4 tons/ha/cycle); in catagories 1,000-1,500 $\mathrm{m}^{2}$ was $2,675 \mathrm{~kg} /$ pond/cycle $(19.7$ tons/ha/cycle) and in catagories $>1.500 \mathrm{~m}^{2}$ was 3,216 $\mathrm{kg} /$ pond/cycle (14.7 tons/ha/cycle) (see Table 4). The cultivation of shrimp farms with the highest productivity of 19.7 tons/ha/cycle obtained in pond with an area of $1,000-1,500 \mathrm{~m}^{2}$ with a ratio value of revenue/cost $(\mathrm{R} / \mathrm{C}$ ) ratio of 1.60 (see Table 5) and the value of the break-even point (BEP) $5,069 \mathrm{~kg}$ of the product and the value of the break-even point (BEP) price of IDR 28,187 (see Table 6).

Table 4. Income (IDR./pond/year)

\begin{tabular}{|c|c|c|c|c|c|}
\hline Parameter & Unit & $<1,000 \mathrm{~m}^{2}$ & $1,000-1,500 \mathrm{~m}^{2}$ & $>1,500-2,500 \mathrm{~m}^{2}$ & Average \\
\hline Ponds & $\mathrm{m}^{2}$ & 636 & 1,357 & 2,191 & 1,300 \\
\hline Production & $\mathrm{kg} /$ pond & 1,105 & 2,675 & 3,216 & 2,208 \\
\hline Production & $\mathrm{kg} / \mathrm{ha}$ & 17,443 & 19,668 & 14,714 & 17,471 \\
\hline Price & IDR. $/ \mathrm{kg}$ & 56,938 & 62,857 & 59,364 & 59,610 \\
\hline Revenue & IDR./pond/year & $39,446,750$ & $189,750,636$ & $107,692,955$ & $109,079,985$ \\
\hline Total Cost & IDR./pond/year & $153,248,875$ & $318,770,793$ & $464,018,409$ & $293,145,746$ \\
\hline Income & IDR./pond/year & $192,695,625$ & $508,521,429$ & $571,711,364$ & $402,225,732$ \\
\hline
\end{tabular}

Table 5. Revenue/Cost (R/C) Ratio

\begin{tabular}{lcccrr}
\hline \multicolumn{1}{c}{ Parameter } & Unit & $<1,000 \mathrm{~m}^{2}$ & $1,000-1,500 \mathrm{~m}^{2}$ & $>1,500-2,500 \mathrm{~m}^{2}$ & \multicolumn{1}{c}{ Average } \\
\hline a. Income & IDR & $192,695,625$ & $508,521,429$ & $571,711,364$ & $402,225,732$ \\
b. Fix Cost & IDR & $46,015,234$ & $76,608,393$ & $113,727,500$ & $74,628,384$ \\
c. Variabel Cost & IDR & $107,233,641$ & $242,162,400$ & $350,290,909$ & $218,517,362$ \\
d.Total Cost & IDR & $153,248,875$ & $318,770,793$ & $464,018,409$ & $293,145,746$ \\
e. R/C rasio (a/d) & Unit & 1.26 & 1.60 & 1.23 & 1.37 \\
\hline
\end{tabular}

Table 6. Break Even Point (BEP)

\begin{tabular}{llrrrr}
\hline \multicolumn{1}{c}{ Parameter } & \multicolumn{1}{c}{ Unit } & \multicolumn{1}{c}{$<1,000 \mathrm{~m}^{2}$} & $1,000-1,500 \mathrm{~m}^{2}$ & $>1,500-2,500 \mathrm{~m}^{2}$ & \multicolumn{1}{c}{ Average } \\
\hline Fix Cost & IDR & $46,015,234$ & $76,608,393$ & $113,727,500$ & $74,628,384$ \\
Variabel Cost & IDR & $107,233,641$ & $242,162,400$ & $350,290,909$ & $218,517,362$ \\
Total Cost & IDR & $153,248,875$ & $318,770,793$ & $464,018,409$ & $293,145,746$ \\
Price & IDR/kg & 56,938 & 62,857 & 59,364 & 59,610 \\
Production & $\mathrm{kg}$ & 1,105 & 2,675 & 3,216 & 2,208 \\
BEP product & $\mathrm{kg}$ & 2,722 & 5,069 & 7,884 & 4,909 \\
BEP price & IDR & 37,483 & 28,187 & 37,494 & 34,312 \\
\hline
\end{tabular}


Vannamei shrimp in the ponds in the village of Karanganyar, Purworejo Regency have average area of $2,791 \mathrm{~m}^{2}$. Break even products amounted to $249 \mathrm{~kg}$ and the value breakeven price of shrimp IDR 20,072 and R/C ratio of 1.73. The cost structure vannamei shrimp farming in ponds for fixed cost of $4 \%$ and variable cost of $96 \%$ of the total cost (preparation cost $7.22 \%$; seed costs $19.49 \%$; feed cost $65.33 \%$; maintenance costs $6.63 \%$ and harvesting costs 1.34\%) (Irawan, 2010). The vannamei white shrimp culture in Pandansimo Village coastal area of Bantul Regency was feasible. The shrimp production in $>1,500 \mathrm{~m}^{2}$ ponds was 4,213 $\mathrm{kg}$; in $1,000-1,500 \mathrm{~m}^{2}$ ponds was $2,538 \mathrm{~kg}$; and in $<1,000 \mathrm{~m}^{2}$ ponds was $1,584 \mathrm{~kg}$. The highest productivity of shrimp was 21.6 tons/ha cultured in the $>1,500 \mathrm{~m}^{2}$ ponds with incomed 94,232,171 rupiah/cycle, the revenue/cost ratio ( $\mathrm{R} / \mathrm{C}$ ratio) 1.51, breakeven point (BEP) of products 965.49 $\mathrm{kg}$ and break even point (BEP) of price 40,248 .71 rupiah (Suparyanti, 2015 $5^{\mathrm{b}}$ ).

Production costs are the compensation received by owners of the factors of production, or the costs incurred by farmers in the production process (Daniel, 2004). Farming are two types of costs: (1) costs in the form of cash, such as labor costs, procurement costs fishery production facilities, and (2) the cost in kind (goods) for example to crops (Yasin, 2013).

\section{Conclussion}

White shrimp culture (Litopenaeus vannamei) in coastal sandy soil area of Bantul Regency was an intensive system with average pond width $1,300 \mathrm{~m}^{2}$; the stocking density 146 seeds $/ \mathrm{m}^{2}$; the feed (33-36\% protein) was given as much as $2,668 \mathrm{~kg} /$ pond/cycle $\quad(20.5$ tons/ha/cycle); the 83 days of culture; shrimp production of $2,275 \mathrm{~kg} / \mathrm{pond} /$ cycle $(17.5$ ton/ha/cycle) and feed conversion ratio (FCR) 1.2. The most production of shrimp was 2,673 $\mathrm{kg} /$ pond $\left(1.357 \mathrm{~m}^{2}\right) /$ cycle $(19.7$ tons/ha/cycle) obtained in categories $1,000-1,500 \mathrm{~m}^{2} /$ pond, with a revenue/cost $(\mathrm{R} / \mathrm{C})$ ratio of 1.60 and the breakeven point (BEP) of $5,069 \mathrm{~kg}$ of the product and the break-even point (BEP) of the price of IDR 28,187 .

\section{Aknowledgement}

We would like to thank the Directorate of Research and Community Service, the Directorate General for Research and Development, the Ministry of Research, Technology and Higher Education, assigned to the Institute for Research and Community Service of Universitas Gadjah Mada, which has provided funds in the Excellence Research Grant Program of Higher Education for the Fiscal Year 2016, with the Assignment Agreement Letter of Program Implementation number: 015 / SP2H / LT / DRPM / II / 2016, dated the 17 of February 2016.

\section{References}

Ambarwati, B. Triyatmo, and Suadi. 2016. Technical aspect of white shrimp (Litopeneaus vannamei) in Bantul Coastal sandy soil area. Proceedings of the $12^{\text {th }}$ Annual National Seminar on Fisheries and Marine Research in 2016. Department of Fisheries and Marine Resources, Faculty of Agriculture, Universitas Gadjah Mada. Yogjakarta, August $8^{\text {th }}, 2016$.

Daniel, M. 2004. Introduction to agricultural Economics. Jakarta. Bumi Aksara.

Djumanto, Ustadi, Rustadi, and B. Triyatmo. 2016. Feasibility Study on the Profitability of Vannamei Dhrimp Aquaculture on Coastal Area of Keburuhan Village,Purworejo Regency. Aquacultura Indonesiana, 17 (1) : 7-11.

FAO/NACA/UNEP/WB/WWF. 2006. International Principles for Responsible Shrimp Farming. Network of Aquaculture Centres in AsiaPasific (NACA). Bangkok, Thailand.

Gay, L.R. and P.L. Diehl. 1992. Research Methods for Business and. Management, MacMillan Publishing Company, New York

Irawan, H. 2010. Technical and financial analysis of white shrimp (Litopenaeus vannamei) culture In Purwodadi Sub-Regency, Purworejo Regency. Faculty of Agriculture, Universitas Gadjah Mada.

Suparyanti, B. Triyatmo, and Sukardi. 2015 . Technical aspect of white shrimp (Litopeneaus vannamei) in Pandansimo Coastal sandy soil area, Bantul Regency. Proceedings of the $12^{\text {th }}$ Annual National Seminar on Fisheries and Marine Research in 2105. Department of Fisheries and Marine Resources, Faculty of Agriculture, Universitas Gadjah Mada. Jogjakarta, August $8^{\text {th }}, 2015$.

Suparyanti, Sukardi, and B. Triyatmo. 2015 . Financial aspect of white shrimp (Litopeneaus vannamei) in Pandansimo Coastal sandy soil area, Bantul Regency. Proceedings of the $12^{\text {th }}$ Annual National Seminar on Fisheries and Marine Research in 2105. Department of Fisheries and Marine Resources, Faculty of Agriculture, Universitas Gadjah Mada. Jogjakarta, August $8^{\text {th }}, 2015$. 
Triyatmo, B. 2001. Study on Coastal Land Sustainability for Pond in Ngombol Regency Purworejo regency. Gadjah Mada University Journal of Fisheries Science. ISSN: 08536384. III (2) : 19-26.

Triyatmo, B. 2015. Development of Shrimp-culture Ponds Based on the Landforms and the Water Quality Dynamics in Coastal Area along Pasir-Jati River. Proceedings of $1^{\text {ST }}$ International Symposium for Marine and
Fisheries Research in 2015. Department of Fisheries and Marine Resources, Faculty of Agriculture, Universitas Gadjah Mada. Yogyakarta, August 7, 2015.

Yacob, I. 2003. Studi Kelayakan Bisnis. Rineka Cipta. Jakarta

Yasin, M. 2003. Business economics analysis of shrimp culture based ponds width in Moutong Parigi Regency, Central Sulawesi Province. AgrIBA $2^{\text {nd }}$ Scientific Journal. 